\title{
Assessment of Management Strategies for Selected Forest Reserves in Ibadan, Oyo State, Nigeria.
}

\author{
Agbi T. T. \\ Department of crop and environmental protection, \\ Ladoke Akintola University of Technology, Ogbomoso, Oyo state. \\ Alamu L. 0. \\ Department of crop and environmental protection, \\ Ladoke Akintola University of Technology, Ogbomoso, Oyo state. \\ Oladiti A. A. \\ Department of general studies, \\ Ladoke Akintola University of Technology, Ogbomoso.
}

\begin{abstract}
Forests reserve management strategies should provide comprehensive forest working plan for each Forest Reserve, consolidate the existing forest reserves, carry out periodic National Forest Resources inventory, Involve communities in the management of forest reserves with clearly defined roles and responsibilities, promote equitable benefit sharing and designate roles and responsibilities amongst stakeholders, protect the Forest Estate from fire and encroachment, encourage multiple-use concepts in the management of forest reserves. Most of these management strategies are mostly only protected on paper, as the forest continues to be subjected to official and unofficial unsustainable logging, and virtually unrestrained firewood and plant collecting. This study assessed the management strategies for selected forest reserve schemes in Ibadan, Oyo state, Nigeria. The study analyzed the respondents' socio demographic characteristics, their level of knowledge on the forest reserve management and level of agreement on the identified Government policies for forest reserve maintenance. Forty (40) questionnaire packs were administered on the workers of Onigambari forest reserves (10), Oluyole Local Government Area, Oso forest reserve (5) and Ijaye forest reserve (5), Akinleye Local Government Area, Moniya, the staff and students in the university of Ibadan, department of forest and forest products (4), the neighboring communities around the forests (4) and the staff in the ministry of Agriculture, Natural resources and Rural development, Ibadan (12). Likert scale was used to rank the knowledge level of the respondents, simple descriptive statistics such as frequency mean and percentages was used to describe the socio-demographic characteristics of the respondents. To test the hypothesis, Pearson correlation demographic analysis was used to test the significant relationship between the selected demographic variables and the dependent variables. The result of the findings showed that some of the selected demographic variables such as marital status $\left(r=0.670^{* *} ; \mathrm{p}<=0.01\right)$, occupation $\left(r=0.544^{* *} ; p<=0.01\right)$ and years of occupational experience $\left(r=0.382^{*} ; p<\right.$ $0.05)$ respectively exhibited a significant relationship with the dependent variable that is perception of level of knowledge on the forest resource management). This implies that all the demographic variables have decisive influence on the dependent variable. Furthermore, the status of management of selected forest reserves in Ibadan was discovered to be inadequate and the stakeholders have proper knowledge of the forest resources management and the policies. There is need for incentives so that stakeholders and other practitioners can adequately use their knowledge to improve on forest management in the study area.
\end{abstract}

Keywords: Forest reserve, management strategies, forest, policies, forest management 


\section{INTRODUCTION}

The objectives of forest management are embodied in National Forest Policy of the country which states that Nigeria's natural resources and environment is to be conserved and used for the collective benefit of the people and to be replenished for the benefit of future generations (Adeyoju, 2001). Forest management is the branch of forestry concerned with the overall administrative, economic, legal, and social aspects and with the essentially scientific and technical aspects, especially silviculture, protection, and forest regulation. A major strategy adopted to ensure that the country's tropical forests are not completely lost has been the establishment of Forest Reserves in different parts of the country. Forest reserves are ecological sites set aside primarily for the conservation of flora and fauna. They are used to protect genetic diversity and enhance the production of forest products such as poles, saw logs, pulp and paper, timber, leaves and herbs, among others (Isichei, 1995; Adesina, 2001). They help to preserve the genetic pool of the forest ecosystems (Salami, 1999) and are important in the scientific studies of the tropical forests (Okali, 1991; Isichei, 1995).

Public concern regarding forest management has shifted from the extraction of timber to the preservation of additional forest resources, including wildlife and old growth forests, protecting biodiversity, watershed management, and recreation, protecting areas with fragile ecosystems, maintaining the diversity of life and developing new natural products for medicines (FAO, 2001).

Across the country, and based on the forest type and ecological conditions, forests are managed for the overall interest of the people. In mangrove areas, forests are managed to help moderate soil, hydrological and aquatic systems. This includes to maintain clean water including e.g. healthy fish populations, as well as to reduce risks or impacts of floods and erosion. In the savannah area, forest management comprises of plantings for various purposes such as shelterbelt, watershed conservation, rehabilitation of degraded sites, desertification control, and mitigation of drought effect. The forests provide the raw materials for both primary and secondary industries while generating employment for a sizeable number of the people. Some of the forest reserves in Nigeria are Olokemeji forest reserve, Oyo state, Onigambari forest reserve, Oyo state, Akure/Ofosu forest reserves, Ondo, Idanre forest reserve, Osun, Ifon/Owo forest reserves, Ondo, Oba hills forest reserve, Osun, Oluwa forest reserve, Ondo, Ngel-Nyaki forest reserve, plateau, Afi River Forest Reserve, Cross river state, IITA forest reserve, Ibadan, Okumu forest reserve, Benin, Edumanom forest reserve, Niger delta, Akassa forest reserves, Niger delta etc. There are in place 32 game reserves/sanctuaries and 7 National Parks covering a total of about 4,293,800 hectares scattered in different areas of the country; 12 Strict Nature Reserves; 13 proposed Game Reserves/National Parks covering about 372,000 hectares located across the country. About 445 forest estates located in different ecological zones of the country covering a total of about 9,652,000 hectares have been legally constituted (FAO, 2000).

Several studies (Alao, 2005; Akindele, 2008; Akande et al, 2009) affirm that most state forestry services charged with the responsibility of managing the forest estate are underemployed or understaffed. Productivity is therefore generally low. In a similar vein, Popoola (2014) noted that in the last 20 years, forest and park rangers, guards, and other technical staff who were adequately equipped and lived within and around such forests, have all vanished due to inept governance, thus exposing the forest estates in many parts of Nigeria to encroachment and other vices. He also observed that where forest guards and rangers exist sparsely, they are poorly kitted, inadequately armed and poorly remunerated, hence they easily compromise. 


\section{MATERIALS AND METHODS}

A 5- level likert scale questionnaire was used for this study and was divided into three (3) parts which included: The socio-demographic characteristics of the respondents, the level of knowledge of the respondents on the forest reserves management and the level of agreement of the respondents on the Government policies for forest reserve management.

Purposeful sampling was employed when selecting the respondents. It is a technique widely used in qualitative research for the identification and selection of information (Patton, 2002). It is also said to be a sampling technique in which the researcher relies on his or her own judgment when choosing members of population to participate in the study (Saunders, 2012).The questionnaire were administered to the workers of: Onigambari forest reserve, Oluyole LGA, Oso forest reserve and Ijaye forest reserve, Akinyele LGA, Moniya, the neighboring communities around the forests, the staffs and students in the university of Ibadan, department of forest and forest products and the staffs in the ministry of Agriculture and natural resources, Ibadan.

Likert scale was used to rank the knowledge level of the respondents, simple descriptive statistics such as frequency mean and percentages was used to describe the socio-demographic characteristics of the respondents. To test the hypothesis, Pearson correlation demographic analysis was used to test the formulated hypothesis of the study.

\section{Socio-economic characteristics of the respondents}

\section{RESULTS AND DISCUSSION}

This section explains the socio-economic variables measured in this study and result in Table 1 reveals that $75.0 \%$ of the respondents sampled were male, while $25.0 \%$ were female. This suggests that majority of the respondents are male compared with the female counterparts. This may be due to the nature of the research work. Majority $(65.0 \%)$ of the respondent are between $41-50$ years with respect to age, while $20.0 \%$ are between $31-40$ years of age, $12.5 \%$ are between 20-30 years of age and only $2.5 \%$ are above 50 years of age. This implies that most of the respondents are adult and it is expected that they would have more knowledge on the forest and likely government reserve policies schemes.

Majorities (92.5\%) are married and 7.5\% are single. Also, $80.0 \%$ are civil servant, $7.5 \%$ are farmers, 5.0 are artisan and $7.5 \%$ have other occupation. This implies that majority of the respondent are elite and it is expected that they would be conversant with the forest land and government intention and associated policies to forest reserve. The result implies that all the respondents sampled are not novice and indicates that they should be knowledgeable on the forest reserve and government attitude towards its maintenance and associated reserve policies especially among the government official and the forest neighboring communities' inhabitants. The result further revealed that more than half (55.0\%) of the respondents have tertiary education, while $25.0 \%$ have secondary education and only $20.0 \%$ have primary education. This implies that majorities (55.0\%) are foresters; while the others are nonforesters i.e. those that stay in the forest reserve neighboring communities.

Again all the respondents have certain number of years of experience associated with their different occupation i.e. as foresters and forest neighboring communities occupants (farmers), while the mean years of experience is 42. This implies that the respondent's years of experience is expected to have impact on their level of knowledge on the forest resources management and their perception of identified government policies for forest reserve maintenance. 
Table 1: Distribution of respondents by socio-economic characteristics $\mathbf{n}=\mathbf{4 0}$

\begin{tabular}{lcc}
\hline Socio-economic variables & Frequency & Percentage \\
\hline SEX & 30 & 75.0 \\
Male & 10 & 25.0 \\
Female & & \\
AGE & 5 & 12.5 \\
$20-30$ & 8 & 20.0 \\
$31-40$ & 26 & 65.0 \\
$41-50$ & 1 & 2.5 \\
Above 50 & 42 & - \\
Mean & & \\
MARITAL STATUS & 3 & 7.5 \\
Single & 37 & 92.5 \\
Married & - & - \\
Divorced & & \\
OCCUPATION & 32 & 80.0 \\
Civil servant & 3 & 7.5 \\
Farmer & 2 & 5.0 \\
Artisan & 3 & 7.5 \\
Others & & \\
LEVEL OF EDUCATION & 8 & 20.0 \\
Primary education & 10 & 25.0 \\
Secondary education & 22 & 55.0 \\
Tertiary education & & \\
YEARS OF EXPERIENCE & 12 & 30.0 \\
11-20 & 14 & 35.0 \\
21-30 & 7 & 17.5 \\
31-40 & 7 & 17.5 \\
Above 40 & &
\end{tabular}

Source: Field survey, 2018.

\section{Level of knowledge on the forest resources management}

For this objective 5 level likert scale of very high (VH); high (H); moderate (M); low (L); and very low (VL) respectively. Mean was also computed which was eventually used for ranking to determine the knowledge level of the respondents on the forest resources management.

The result in table 2 revealed that the permit fees are paid to the Government for the use of forest products; punishment i.e. payment of fines, imprisonment are given to those that violates the law and the forest workers and guards are always available to keep the forest from trespassers and unauthorized grazers respectively have highest weighted mean score (WMS) of 4.05 each and they were ranked $1^{\text {st }}$, followed by the statement that the forest resources are sufficient to meet the demand of the wood raw materials i.e. fuel wood, log wood etc. by industries and mills ranked $4^{\text {th }}(\mathrm{WMS}=3.85)$. The statement that there is a record for every activities going on in the forest i.e. number of trees fell, species of the trees replanted etc. (WMS $=3.78 ; 5^{\text {th }}$ ), the Government (local, state and federal) is committed to the maintenance of the forest reserves (WMS $=3.15 ; 6^{\text {th }}$ ) were ranked in similar order, while the statement that trees that are fallen are replanted had the least weighted mean score of 2.35 and was ranked $10^{\text {th }}$.

The result above implies that the respondents' knowledge level on the forest resources management varied. The variation in their knowledge level may be due to difference in their age, years of working experience and educational level. 
Table 2: Distribution of respondent by their level of knowledge on the forest resource management.

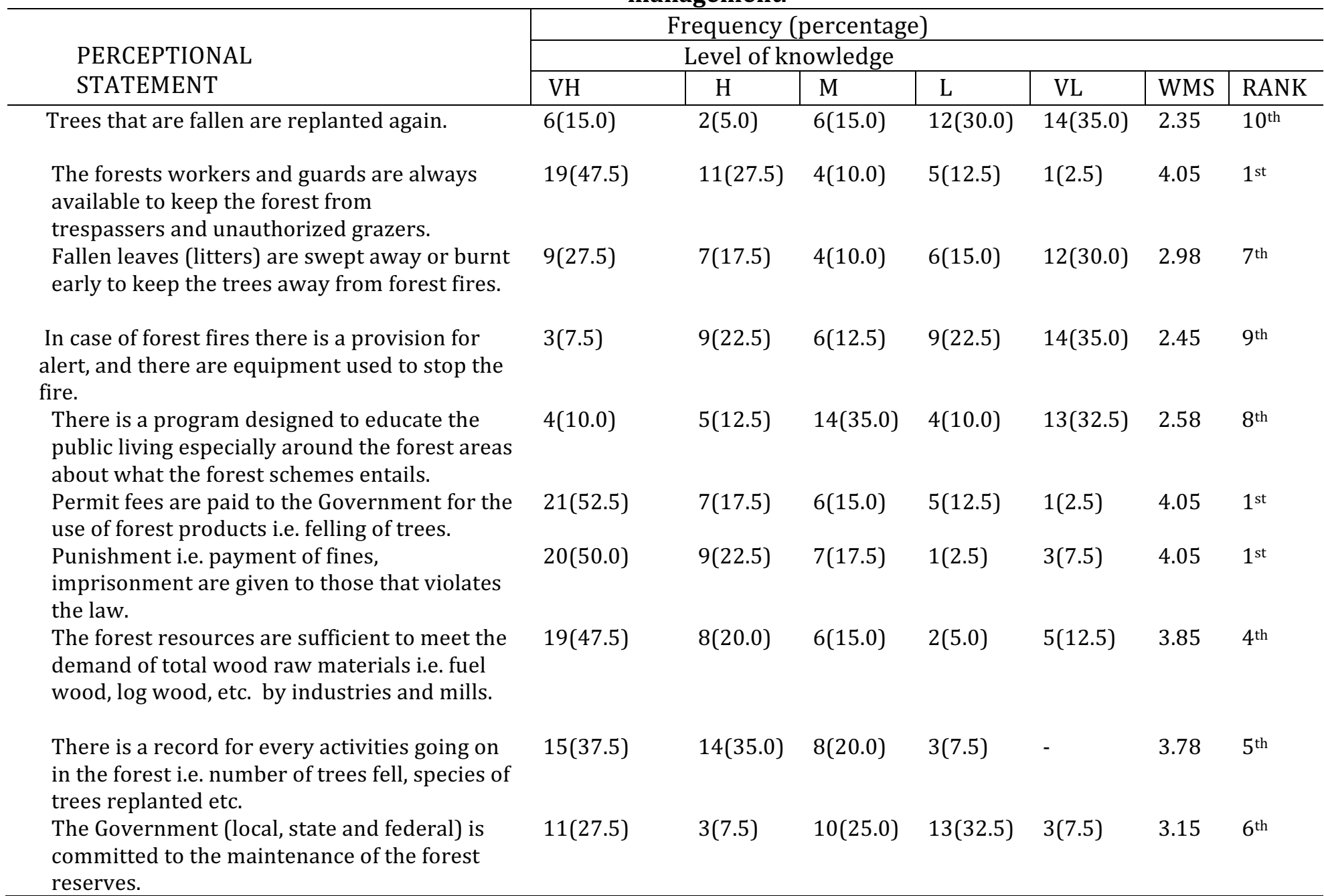

Source: Field survey, 2018.

Perceived roles of government policies for forest reserve management.

For this objective, five level likert scale of strongly disagree (SA); agree (A); undecided (U); disagree (D); and strongly disagree (SD) respectively. Weighted mean score was calculated which was used to determine the ranking order of perceptional statement regarding the roles of government policies for forest reserve maintenance.

Table 3 revealed the statement that the development and conservation of national timber forest products (NTFP) in all the ecological zone for the benefits of the present and future generations and to increase NTFP's contribution to the national economy had the highest weighted mean score (WMS) of 4.43; followed by the statement that maintenance of competent forest administration manned by efficient forest officers (WMS $=4.33 ; 2^{\text {nd }}$ ), reformation of the forest reserve system in order to create an enabling environment for sustainable forest management (WMS $=4.25 ; 3^{\text {rd }}$ ) and the statement that promotion of forestry in order to provide aesthetics, recreational, social and economic values and benefits to the people (WMS $=4.13 ; 4^{\text {th }}$ )respectively. Again the statement that partnership with rural communities for the sustainable management in forest resources to ensure the supply of goods and services from the forest for the present and future generation (WMS=4.10); to prevent water and wind erosion, the government recognizes and emphasizes the protective role of forests in watersheds, buffer zones around rivers (WMS $=4.00)$ and activity involving women in forestry policy enunciation, implementation and sustainable management of forest resources 
(WMS=3.95) were ranked $5^{\text {th }}, 6^{\text {th }}$ and $7^{\text {th }}$ respectively, while the statement that effective and efficient measures for prevention, control and management of forest fires had the least WMS of 3.88 and was ranked last $\left(10^{\text {th }}\right)$.

This implies that all the respondents have different perception on the government policies for forest reserve maintenance. The variation in their level of agreement on the identified policies may be due to differences in their perception and knowledge level of individual on the various roles of government policies as it affects forest reserve management and this is responsible for the different ranking order as indicated in Table 3.

Table 3: Distribution of respondents by level of agreement on the identified Government policies for forest reserve maintenance.

\begin{tabular}{|c|c|c|c|c|c|c|c|}
\hline \multirow[b]{3}{*}{ PERCEPTIONAL STATEMENT } & \multicolumn{7}{|c|}{ Frequency(percentage) } \\
\hline & \multicolumn{7}{|c|}{ Level of agreement } \\
\hline & SA & A & $\mathrm{U}$ & DA & SA & WMS & RANK \\
\hline $\begin{array}{l}\text { Promotion of forestry in order to provide } \\
\text { aesthetics, recreational, social and economic } \\
\text { values and benefits to the people. }\end{array}$ & $22(55.0)$ & $13(32.5)$ & $3(7.5)$ & $2(5.0)$ & - & 4.13 & $4^{\text {th }}$ \\
\hline $\begin{array}{l}\text { To prevent water and wind erosion, the } \\
\text { government recognizes and emphasizes the } \\
\text { protective role of forests in watersheds, buffer } \\
\text { zones around rivers. }\end{array}$ & $13(32.5)$ & $19(47.5)$ & $4(10.0)$ & $3(7.5)$ & $1(2.5)$ & 4.00 & $6^{\text {th }}$ \\
\hline $\begin{array}{l}\text { Actively involving women in forestry policy } \\
\text { enunciation, implementation and sustainable } \\
\text { management of forest resources. }\end{array}$ & $11(27.5)$ & $20(50.0)$ & $6(15.0)$ & $2(5.0)$ & $1(2.5)$ & 3.95 & $7^{\text {th }}$ \\
\hline $\begin{array}{l}\text { The development and conservation of National } \\
\text { Timber forests products (NTFP) in all the } \\
\text { ecological zones for the benefits of the present } \\
\text { and future generations and to increase NTFP's } \\
\text { contribution to the national economy. }\end{array}$ & $15(37.5)$ & $15(37.5)$ & $4(10.0)$ & $4(10.0)$ & $2(5.0)$ & 4.43 & $1^{\text {st }}$ \\
\hline $\begin{array}{l}\text { Government promotes the rehabilitation and } \\
\text { conservation of forests that protects the soil and } \\
\text { water in the nation's key watersheds and river } \\
\text { system. }\end{array}$ & $16(40.0)$ & $10(25.0)$ & $9(22.5)$ & $5(12.5)$ & - & 3.93 & $8^{\text {th }}$ \\
\hline $\begin{array}{l}\text { Partnership with rural communities for the } \\
\text { sustainable management in forest resources to } \\
\text { ensure the supply of goods and services from the } \\
\text { forest for the present and future generations. }\end{array}$ & $19(47.5)$ & $12(30.0)$ & $2(5.0)$ & $4(10.0)$ & $3(7.5)$ & 4.10 & $5^{\text {th }}$ \\
\hline $\begin{array}{l}\text { Sustainable management and utilization of forest } \\
\text { resources to guarantee and encourage the } \\
\text { perpetual supply to raw materials to the forest } \\
\text { fires. }\end{array}$ & $17(42.5)$ & $8(20.0)$ & $11(27.5)$ & $3(7.5)$ & $1(2.5)$ & 3.93 & $8^{\text {th }}$ \\
\hline $\begin{array}{l}\text { Reformation of the forest revenue system in } \\
\text { order to create an enabling environment for } \\
\text { sustainable forest management. }\end{array}$ & $24(60.0)$ & $7(17.5)$ & $5(12.5)$ & $3(7.5)$ & $1(2.5)$ & 4.25 & $3^{\text {rd }}$ \\
\hline $\begin{array}{l}\text { Effective and efficient measures for prevention, } \\
\text { control and management of forest fires. }\end{array}$ & $17(42.5)$ & $10(25.0)$ & $7(17.5)$ & $3(7.5)$ & $3(7.5)$ & 3.88 & $10^{\text {th }}$ \\
\hline $\begin{array}{l}\text { Maintenance of competent forest administration } \\
\text { manned by efficient forest officers. }\end{array}$ & $28(70.0)$ & $4(10.0)$ & $4(10.0)$ & $1(2.5)$ & $3(7.5)$ & 4.33 & $2^{\text {nd }}$ \\
\hline
\end{tabular}

Source: Field survey, 2018. 


\section{Test of the hypothesis}

Test of the significant relationship between the selected demographic characteristics of the respondents and their perception of knowledge on the forest resource management in the area.

For this hypothesis, Pearson correlation demographic analysis was used. The demographic variables used in the analysis includes sex, age, marital status, occupation, years spent in school and years of occupational experience respectively.

According to the result of the analysis in Table 4, some of the selected demographic variables such as marital status ( $\left.\mathrm{r}=0.670^{* *} ; \mathrm{p}<=0.01\right)$, occupation $\left(\mathrm{r}=0.544^{* *} ; \mathrm{p}<=0.01\right)$ and years of occupational experience $\left(\mathrm{r}=0.382^{*} ; \mathrm{p}<0.05\right)$ respectively exhibited a significant relationship with the dependent variable (perception of level of knowledge on the forest resource management). This implies that all the aforementioned demographic variables (sex, occupation and years of occupational experience) have decisive influence on the dependent variable.

Therefore, the null hypothesis (Ho) is rejected; hence alternative hypothesis (Ha) is accepted in the like manner.

Ha: There is significant relationship between the selected demographic variables and their perception on the level of knowledge on the forest resources management.

Table 4: Test of significant relationship between the selected demographic variables and the dependent variables (perception of level of knowledge on the forest resources management).

\begin{tabular}{lllll}
\hline Demographic variables & Correlation coefficient & $\mathrm{r}-$ value & Decision & Remark \\
\hline Sex & -0.079 & 0.629 & NS & Accept Ho \\
Age & 0.042 & 0.795 & NS & Accept Ho \\
Marital status & $0.670^{* *}$ & 0.000 & $\mathrm{~S}$ & Reject Ho \\
Occupation & $0.544^{* *}$ & 0.000 & $\mathrm{~S}$ & Reject Ho \\
Years spent in school & -0.127 & 0.436 & $\mathrm{NS}$ & Accept Ho \\
$\begin{array}{l}\text { Years of occupational } \\
\text { experience }\end{array}$ & $0.382^{*}$ & 0.015 & $\mathrm{~S}$ & Reject Ho
\end{tabular}

Source: Data analysis, 2018

**: Correlation is significant at the 0.01 level (2- tailed)

*: Correlation is significant at the 0.05 level (2- tailed)

S: Significant

NS: Non significant

Ho: Null hypothesis

\section{SUMMARY AND CONCLUSION}

The study in its specific objectives described the socio-economic characteristics of the respondents, the level of knowledge on the forest resource management and examined the level of agreement on the identified role of Government policies for forest reserve maintenance. 
Results showed that all the respondents have certain number of years of experience associated with their different occupation i.e. as foresters and forest neighboring communities' occupants (farmers), while the mean years of experience is 42 . This implies that the respondent's years of experience is expected to have impact on their level of knowledge on the forest resources management and their perception of identified government policies for forest reserve maintenance.

The results also revealed that the respondents' knowledge level on the forest resources management varied. The variation in their knowledge level may be due to difference in their age, years of working experience and educational level. All the respondents have different perception on the government policies for forest reserve maintenance. The variation in their level of agreement on the identified policies may be due to differences in their perception and knowledge level of individual on the various roles of government policies as it affects forest reserve management and this is responsible for the different ranking order as indicated in Table 3.

It was concluded that the status of management of selected forest reserves in Ibadan was discovered to be inadequate. Though the trespassers are convicted by the laid down measures according to the gravity of their offences but all measures needed to secure the proper management of the reserve are not well implemented. It also showed that the government's involvement in the development of the forest was discovered to be inadequate or not sufficient.

\section{References}

Adesina, F.A. (2001). Forestry sector response to global climate change: The African Challenge Conflicts and Development Watch, 2: pp. 19-29

Adeyoju, S.K (2001). Forestry for national development: A critique of the Nigerian situation, pp. 55-67. in: Popoola, L, Abu, J.E and Oni, P.I. (Eds.) Forestry and National Development. Proceedings of 27 th Annual conference of Forestry Association of Nigeria held in FCT. Abuja, Nigeria.

Akindele, S.O (2008). Forestry Practices in Nigeria: An Overview

Alao, J.S. (2005). Capacity Building Modules in the Nigerian Forest Services. A Ph.D. Thesis submitted to the University of Ibadan, Ibadan.301p.

Akande, J. A, Larinde, S.L, Ntabe, E, Adu-Anning C. and B.O. Agbeja (2007) Towards Forest Industrial Reform in Ghana, Nigeria and Cameroon. Discovery and Innovation Journal Volume 19 of AFORNET Special Edition No 3: 181-189.

Food and Agriculture Organization (2000). Annual Book of Forest Statistics, FAO Rome.

Food and Agriculture Organization (2001). Criteria and indicators of sustainable forest management of all types of forests and implications for certification and trade. Secretariat Note. 15th session of the Committee on Forestry, 12-16 March 2001. Rome.

Isichei, A.O. (1995): Omo biosphere reserve, current status, utilization of biological resources and sustainable management. Working paper No. 11, 1995, UNESCO (South-South Cooperation Programme), Paris, France.

Okali, D.U.U. (1991). Guidelines for selection of sites and species of conservation interest. Report to Natural Resources Conservation Council, Abuja, Nigeria. Mimeograph.

Patton MQ. Qualitative research and evaluation methods. $3^{\text {rd }}$ sage publications; Thousand Oaks, CA: 2002.

Popoola, L (2014). Boko Haram: Blame the Nigerian state, not Sambisa Forest. Punch Newspaper, June 2.

Salami, A.T. (1999). Vegetation dynamics on the fringes of lowland humid tropical rainforest of southwestern Nigeria - An assessment of environmental change with air photos and Landsat-TM International Journal of Remote Sensing, Vol. 20, No. 6, pp. 1169 - 1181.

Saunders, M., Lewis, P. \& Thorn hill, A. 'Research methods for business students' $6^{\text {th }}$ edition, Pearson education limited. 